に難からず。曲線 L は 5 時間約 $350^{\circ} \mathrm{C}$ に之を保持したる場合にして

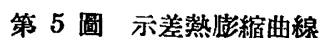
$450^{\circ} \mathrm{C}$ 以前には決して變化起らざる事を示し, 又曲楾 $\mathrm{M}$ は僅に $500^{\circ} \mathrm{C}$ 迄つ加熱挠之を冷却するす尚且つ $400^{\circ} \mathrm{C}$ に於ける膨脹を生ずる事を示や り。曲線 $\mathrm{N}$ は 1 時間 $425^{\circ} \mathrm{C}$ に之を保持したる場合にして $390^{\circ} \mathrm{C}$ 以前 に變化の起らざる事を数へ，若し 3 特間 $430^{\circ} \mathrm{C}$ に之を保持せる場合は

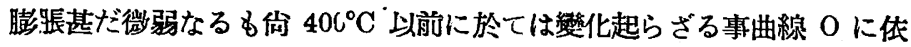
て明白なり。郎ち此變態に於ける加熱；冷却の際の溫度差は過罃或去過 冷現象に基因せるるのにあらざる事を知るべし。又曲線 P は加䇤の際 之を 2 時間 $590^{\circ} \mathrm{C}$ に保持せるも份 $600^{\circ} \mathrm{C}$ 以前に變化を認めざる事を示 せるものなり。

燒入試料を燒戻の際生ずる發熱現象が硬化現象を件ふや否やを檢する

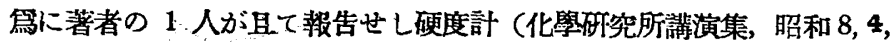
印刷中）に侬りて嬈戻中並に燒戻後に於汁る硬度の測定を行へり。郎ち $5.5 \% \mathrm{Al}$ の場合には燒戻中湘定せし硬度は多少の曲折は有る す大體に於 て燒戻の淮むに從ひ漸次に之を減少すべきる，燒冐後測定せる硬度は $250^{\circ} \mathrm{C}$ 邀に於て著しき增大を示すべし。6.0\% Al の場合は前者に 比して 硬度大なるを以て燒戻中の硬度す燒戻後の硬度す共に增大し $350 \sim: 00^{\circ} \mathrm{C}$ に於て承大傎に到達寸。7.0 7 74\% Al の場合は 同樣なる 溫度に於て更 に著しき硬度の增大を見るべきす，7.76\% Al 以上の場合は蓺戻に依りて 硬度は殆ど增大せざるが珓し。郎ち本合金中巽常發䇾著しき試料に於て
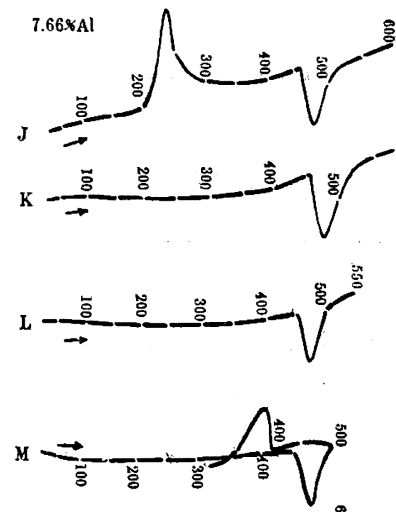

は硬化す亦增大し所謂燒戻硬化をなすべく，而して其硬化現象は異常發熱の直後に於て葓起せらるべく，以上 の政究に依り本合金の燒戻硬化は全く新變態に其主因を有する事を知るべし。

（東京工業大學電氣化學科研究室）

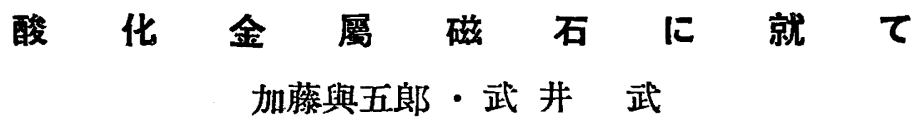

I. 緒 言

磁石は從來金屬製に限られて居つた。然るに吾数室では種々研究の結果，創めて酸化金屬に依て之を製造し 得るに至つた。斯の如く此滋石が從來のものと全然原料を異にする結果其の製法が全然異なるは刎論である。 加之此磁石の性資も亦金電磁石の其と異つた頗る與味あるものが幾多ある。特に頑磁力が大で從て短くとも强 力で馬蹄形たるを要せず，然も磁極の位。置及び數の自由であるか洳きは最す與味ある點である。依て始に其一 端を述べんとする。

\title{
II. 原料及製法
}

本磁石の原料には金屬酸化物特に酸化鐵を基礎として更に酸化コバルト及び他の數種の金屬酸化物を用ふっ 其製造には此等の粉未混合物を加原原縮及び加熱して成形し然る後磁化するを普通とする。而してこの加熱に 
依て化學蘩化が起る。金屬磁石を製するには何れる原料を一度熔啒し然る後種々の加工をなして成形する。こ

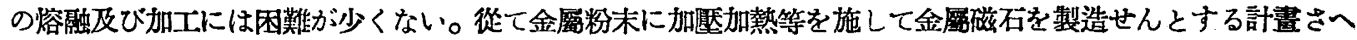
も少くない。然るに本磁石に抸ては酸化金屬を原料となしたる結果この困難なく製造が甚だ容易である。

III. 組 織 及組 成

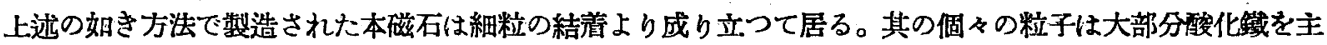
體とする單一な固溶慻より成る。更に詳言すれば各粒子:さ亞鐵酸第一鐵 $\mathrm{FeO} \cdot \mathrm{Fe}_{2} \mathrm{O}_{3}$ (磁鐵鑛) に他の同形酸 化物の溶解せる固溶體と考へられる。而してこの同形酸化物とは 主に亞鐵酸監 $\mathrm{M}^{\mathrm{IIO}} \mathrm{O} \cdot \mathrm{Fe}_{2} \mathrm{O}_{3}$ である。斯の如 く同形の監類例人ば $\mathrm{ZnSO}_{4} \cdot 7 \mathrm{H}_{2} \mathrm{O}$ と $\mathrm{MgSO}_{4} \cdot 7 \mathrm{H}_{2} \mathrm{O}$ とか涸溶體の結晶をなすことは已に能く知らるっ所で ある。叉 $\mathrm{FeO} \cdot \mathrm{Fe}_{2} \mathrm{O}_{3}$ と $\mathrm{ZnO} \cdot \mathrm{Fe}_{2} \mathrm{O}_{3}$ とが固溶遭をなすことは筆者等が代に發表せる所である（日本鐄業會 誌, 第 47 卷, 第 554 號; Trans. Amer. Electrochem. Soc., 1930, LVII, 297)。

本磁石の組成は種々ある。今其組成の一例を示せば炊の如くである。

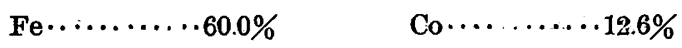

$0 \cdots \cdots \cdot \cdot \cdot 27.4 \%$

而して其の磁性は組成の異なるに隨つて翼る。

IV. 比重

本磁石は酸化物の粉未原料を加劻瓷縮及加熱して作られるが故に其の比重が小である。而して此の比重は加 區及び加熱の程度によつて異る。今其比重の一例を示せば火如くである。

宸素銅磁石 $\fallingdotseq 7.7 \quad$ 本 磁 石

郎ち酸化金屬磁石の比重は金屬磁石の其の牛分以下である。

V. 特性（其 1) 項磁力及び長さと磁力との關係

磁石の良否を制定するには一般に次の 2 點に重きを措くとする。
(1) 牫留磁氣
(2) 頙 磁 力

次に本磁石の履歷曲線を示して此 2 哭哭を䛺明せんとする。

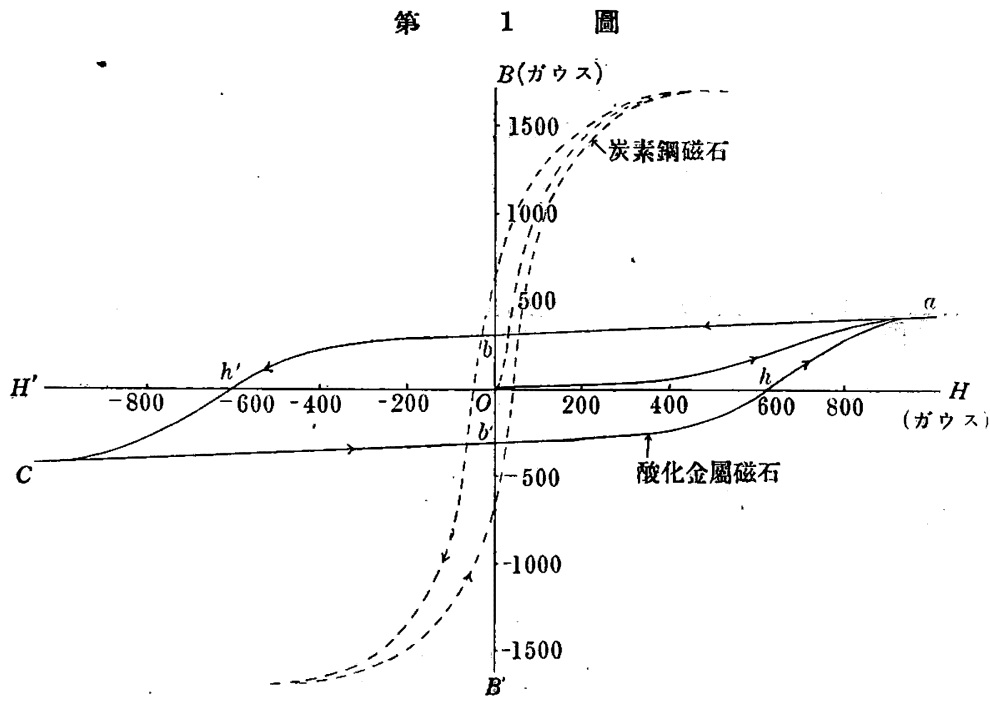

履歴曲線 第 1 圖惯楾 は本磁石の履歷曲線の一例 である。橫軸 $\mathrm{HOH}^{\prime}$ に磁 化する磁場の强さ（嚴密に は有效磁場）を探り縱軸 $B O B^{\prime}$ に磁石の磁化される 强さ(㩔密には磁氣の强さ) を探る。今本磁石を最初磁 場に置いて磁化する時は之 はOa の如く磁化される。 $a$ 點にて所謂飽和磁氣に達 しそれ以上磁場を增しても 磁氣の强さは䜖さざるに至 


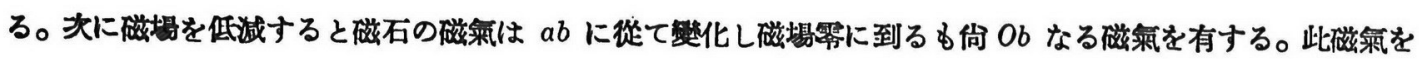
牫噼磁氣と云ふ。

次に磁場を前と反對の方向に作用させると磁石の磁氣の强さは $b h^{\prime}$ に從て變化し $b^{\prime}$ に到りて全く磁氣を头 ふ20 此際 $0 ! l^{\prime}$ を磁石の頑磁力と云ふ心。

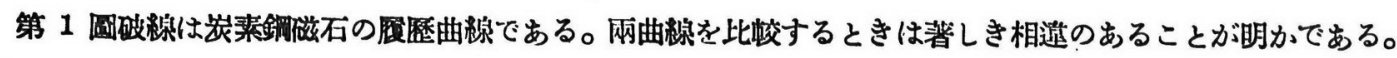

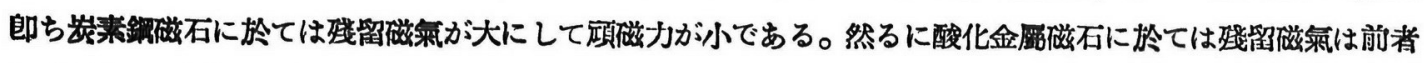

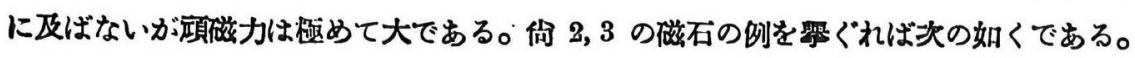

\begin{tabular}{|c|c|c|c|}
\hline 磁 & 惐留磁乘(ガウス) & 碩磁力(ガウス) & 斯の如く項磁力の極めて大であることか酸 \\
\hline 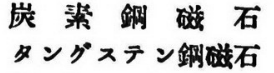 & $\begin{array}{l}600 \sim 700 \\
800 \sim 950\end{array}$ & $\begin{array}{l}45 \sim 60 \\
55 \sim 70\end{array}$ & 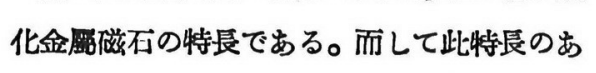 \\
\hline 蠤化金盛磁石 & $250 \sim 350$ & $300 \sim 1000$ & Бには興味ある他の性頑が \\
\hline
\end{tabular}

して來る。例へば磁石を太く短いわのにしても磁力の減少の小なる水及び外界の磁場によつて磁力減耗の頗る 少なき事の如きである。次に之等の特長を今少し詳しく述べん。

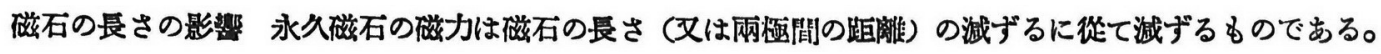
故に强い永久磁石を得んために長さを長くする目的で馬踣形とするのは一般である。この磁力の㳦じ方は磁石 によりて異る。而して頑磁力の大なる磁力程此の減じ方が少ない。酸化金屬磁石は圆杜狀にしてその長さか断

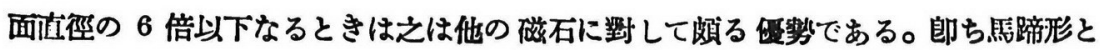
なすことを要せずして强力の磁石となる。第 2 圖は喻狀酸化金屬磁石の 外面と內面 に植を有せしめた一例である。斯の如く雨極を接近させても份强い磁力を存する。

外界磁場の影绵 永久磁石の磁力は一般に外界から磁場が作用されると次第に減 耗する。而してこの減耗し方も磁石の性筫に依て異り碽磁力の大なるものは一般にこ

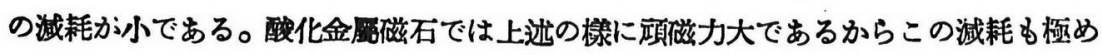
て小である。次に 50 サイクル交番磁場を作用せる場合の炭素鋼隊石との比洨例を舉げる。

\begin{tabular}{|c|c|c|c|c|c|c|c|c|}
\hline 䋦望(ガウス) & 10 & 20 & 40 & 62 & 80 & 100 & 120 & 150 \\
\hline 減耗 $\{$ 醊化金屬磁石 & 砝ど減耗せず & $"$ & " & " & " & " & " & " \\
\hline 䨝\% 宸絷銅磁入 & 7.7 & 12.3 & 30.8 & 51 & 63 & 74 & 84 & $89^{\circ}$ \\
\hline
\end{tabular}

VI. 特性 (搷 2) 磁極の位置と数

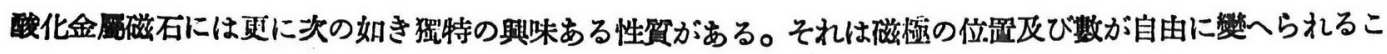
とである。

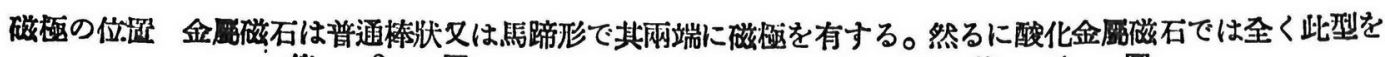
第 3 圖

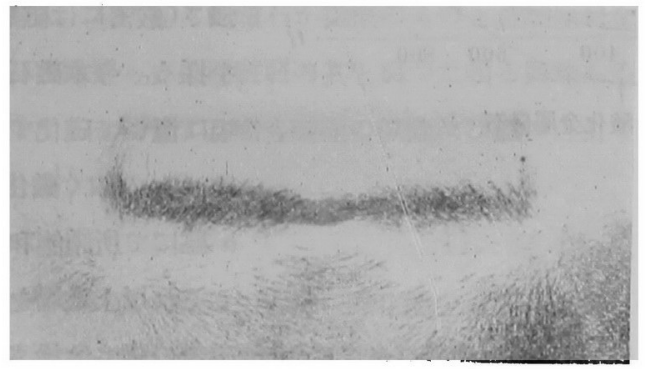
第 4 圆 


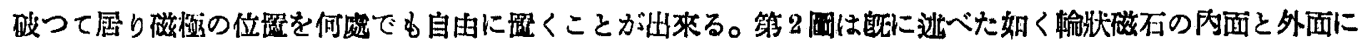

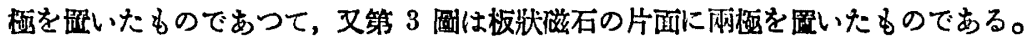

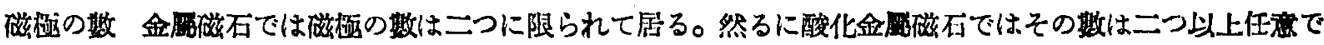

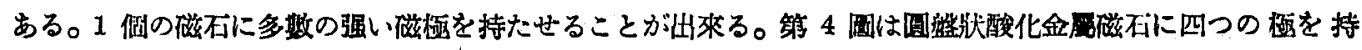
たせた例である。

\section{VII. 金鍶磁石との關係}

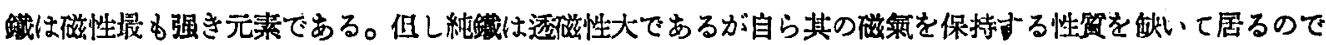

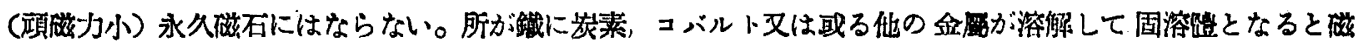
氣保持性か泏て永久磁石となるのである。

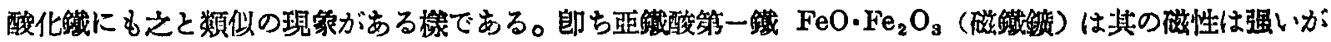

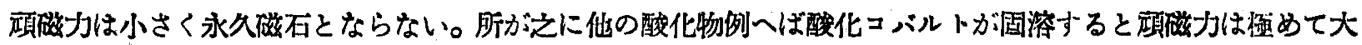
となり永久磁石として適するのである。

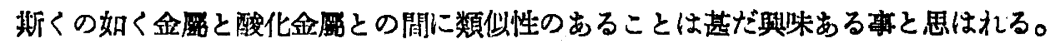

$$
\text { VIII. 概 要 }
$$

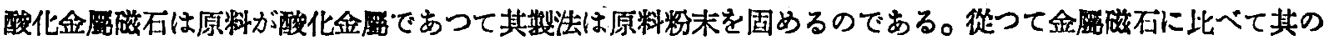
整法が簢吡である。又其の此画が小さい。而して其の磁氣的特微は次の如くである。

1. 碩磁力强大である。2. 馬蹄形となすを要せずして强磁石となる。3. 位柾の位斀及び數が自由である。

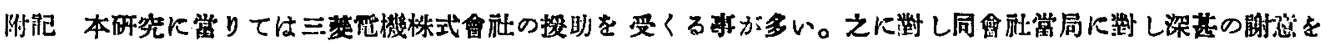

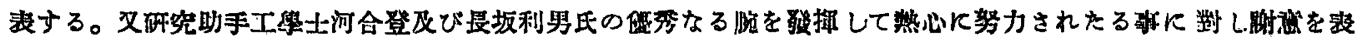
する。

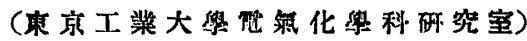

\section{酸 化鉛 の種 類 及び物 理 的性 質 加藤與五郎 · 高瀨理三郎}

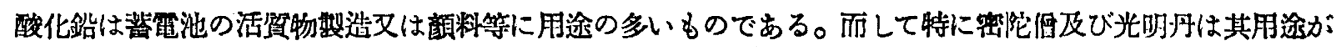
多い，体りて之等に就て砄究せる所を略述せんとする。

滛陀僧

之は PbO のことであるはいふまでもない。之の市肘品は猉色であつて赤味のあるのとないのとがある，而

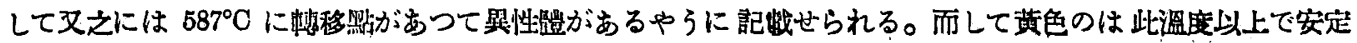
で帶赤色のは以下で安定であることになつて居る，又溫度の昨るときには帶赤色のが涉色に變化し易いか溫度

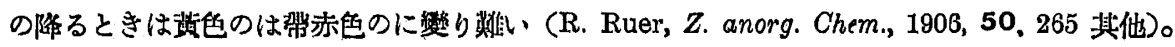

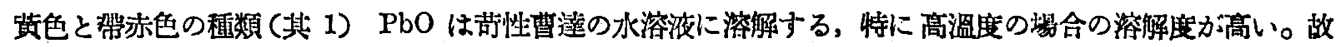

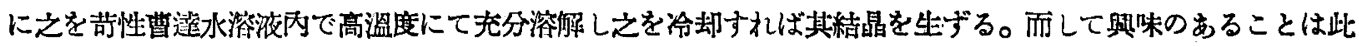

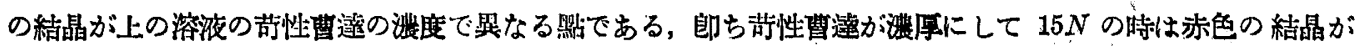

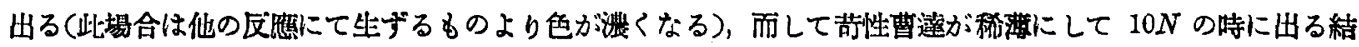

